\title{
Scientific support for the innovative development of sheep breeding in the Russian Federation
}

\author{
Tatiana Marinchenko* \\ Federal State Budgetary Scientific Institution (Rosinformagrotekh FSBSI), Lesnaya Str., \\ 60,Pravdinsky Township, 141261 Moscow Region, the Russian Federation
}

\begin{abstract}
Increasing the output of agricultural products and improving their quality is one of the most important tasks of ensuring the food security of the Russian Federation. The main solution to this problem is the introduction of innovative technologies, which are the result of research and development. In this country, sheep breeding is developing in accordance with the tasks set by the government to increase output, improve quality and develop export potential. Currently, the main livestock of sheep is concentrated among farmers and households, which cannot provide breeding work and the introduction of innovations at the required level. The main consumers of innovations are agricultural organizations, which occupy a small share in terms of livestock and products. The aim of the study is to analyze the scientific potential of the industry from the standpoint of its sufficiency to solve the tasks set by the government.
\end{abstract}

\section{Introduction}

Sheep breeding is out standing in the diversity and uniqueness of the products obtained (wool, lamb meat, milk, furs, sheepskin coats, etc.), in the ability to efficiently produce it through the use of natural and fodder resources in conditions of their limited availability and inaccessibility for other types of farm animals.

As a result of the measures taken in the Russian Federation since 2000, the number of sheep increased 1.6 times and it amounted to 20.65 million heads in all categories of farms by the beginning of 2020 . Most of the sheep population $(42.8 \%)$ is concentrated in the personal subsidiary plots of the population (PSP) and remains stable for many years. The share of the sheep population also remains high in peasant (farm) enterprises (PFE), where $40.7 \%$ of the livestock are already concentrated [1].

At the present stage, the main task of the industry is the intensification of production, which is achieved by increasing the productivity of animals through effective selection work, creating a solid forage base and introducing advanced technologies for the manufacture of sheep products [2].

In this regard, important areas of the state agricultural food policy are to stimulate the development of pedigree sheep breeding and the formation of a competitive domestic

*Corresponding author:9419428@mail.ru 
pedigree base that meets the needs of agricultural producers and allows for the uninterrupted supply of commodity enterprises with highly productive young animals.

The problem of conservation, rational use and improvement of the sheep gene pool in Russia is an important component of the sectoral program and the strategy to be elaborated for the development of the industry for the next decade [3, 4].The development and implementation of the subprogram titled "Improving the genetic potential of small ruminants" of the Federal Scientific and Technical Program will also contribute to the intensive development of the industry.

The diversity of the domestic breed composition is a legacy of the scientific support of previous decades and the basis for the creation of new breeds and types of animals having a high productivity potential and good adaptation to local natural, economic and technological conditions of breeding. The government has set a number of difficult tasks to increase the output of products and improve their quality; in this regard, the analysis of the scientific potential of the industry is relevant.

\section{Results and discussion}

The problem of national economic security including guaranteed food security for the regions occupies one of the central places in the policy of economically developed countries of the world [5]. Special attention is paid to food security in Russia.

As a livestock industry, sheep breeding ranks third in the world andis one of the most extensive types of agriculture. According to the Food and Agriculture Organization of the United Nations (FAO), the global breed gene pool of sheep has more than 1,300 breeds and intra-breed types created to meet human needs for various types of sheep products. The world population of these animals was about 1.2 billion headsin 2018 [6].

The main producers of lamb are Australia, New Zealand, the United Kingdom and Pakistan.The main exporters are Australia, the United Kingdom and New Zealand. Australia, New Zealand, Argentina, Uruguay and Pakistan are the leaders in wool production and its main suppliers to the world market.

In general, the world production of wool decreases by $6 \%$ to $10 \%$ every 5 years, which is due to high competition from the chemical industry, an increase in the production of synthetic fibers, the quality of which is increasing from year to year. However, at the same time, the demand for ultra-fine and super-fine wool remains, and the price is growing. It is profitable to produce wool up to 19 microns along with a high yield of pure fiber [7].

With this in mind, countries that have developed sheep breeding (including those countries that have traditionally been focused on wool production) are making significant efforts to reorient their sheep breeding from wool to meat or to a combined area. Countries that were primarily engaged in the production of mutton have maintained or increased the number of sheep.

Almost every country pays special attention to the production of lamb and young mutton, which accounts for $90 \%$ or more of the total value of the gross output of this industry. Up to $80 \%$ of the gross meat output is obtained from the sale of lambs of early maturing meat and meat-wool breeds of sheep mainly from crossbred sheep breeding [8, 9].The global aim of sheep breeding as an agricultural sector is supplying people with highquality meat, development of the ways of more efficient use of the gene pool of available sheep breeds in order to increase the level and the quality of meat [10].

In Russia, sheep breeding is a dedicated branch of animal husbandry having a gene pool of more than 40 sheep breeds. A stable positive trend has already been observed in sheep breeding for 20 years. During this period, the livestock of sheep increased 1.6 times and it amounted to 20.65 million heads in all categories of farms by the beginning of 2020 , including 8.8 million heads in private household plots, 8.4 million heads in peasant (farm) 
enterprises and individual entrepreneurs, and 3.4 million heads in agricultural organizations [1]. The main livestock is concentrated in private household plots $(42.8 \%)$, peasant (farm) enterprises and individual entrepreneurs $(40.7 \%)$. The number of sheep in agricultural enterprises is only $16.5 \%$ of their total number (Table 1 ).

Table 1. Livestock of sheep in Russia as of the end of the year, ' 000 heads[1,11].

\begin{tabular}{|l|c|c|c|c|c|c|}
\hline Farm categories & $\mathbf{2 0 1 5}$ & $\mathbf{2 0 1 6}$ & $\mathbf{2 0 1 7}$ & $\mathbf{2 0 1 8}$ & $\mathbf{2 0 1 9}$ & $\begin{array}{c}\text { Livestock } \\
\text { structure by } \\
\text { farm } \\
\text { category, \% }\end{array}$ \\
\hline $\begin{array}{l}\text { Farms of all } \\
\text { categories }\end{array}$ & 22443.0 & 22662.4 & 22347.3 & 21136.4 & 20655.0 & 100 \\
\hline $\begin{array}{l}\text { Agricultural } \\
\text { enterprises }\end{array}$ & 4133.2 & 4024.5 & 3876.3 & 3562.2 & 3413.8 & 16.5 \\
\hline $\begin{array}{l}\text { Private household } \\
\text { plots }\end{array}$ & 9865.3 & 9748.9 & 9688.2 & 9159.4 & 8841.5 & 42.8 \\
\hline $\begin{array}{l}\text { Peasant (farm) } \\
\text { enterprises and } \\
\text { individual } \\
\text { entrepreneurs }\end{array}$ & 8444.5 & 8889.0 & 8782.8 & 8414.8 & 8399.6 & 40.7 \\
\hline
\end{tabular}

Therefore, the main producers of meat and wool are private household plots and Peasant (farm) enterprisesand individual entrepreneurs, which together account for $92.3 \%$ of sheep and goat meat in slaughter weight and $84.9 \%$ of wool in physical weight (Table 2) [1, 12].

Table 2. Structure of production of the main products of sheep breeding in the Russian Federation, percent of the total production.

\begin{tabular}{|l|c|c|c|c|c|c|}
\hline \multicolumn{1}{|c|}{ Indicator } & $\mathbf{2 0 1 5}$ & $\mathbf{2 0 1 6}$ & $\mathbf{2 0 1 7}$ & $\mathbf{2 0 1 8}$ & $\mathbf{2 0 1 9}$ \\
\hline & \multicolumn{5}{|c|}{ Agricultural enterprises } \\
\hline $\begin{array}{l}\text { Sheep and goats in slaughter weight, '000 } \\
\text { metric tons }\end{array}$ & 7.9 & 7.6 & 7.1 & 7.8 & 7.7 \\
\hline Wool (in physical weight), metric tons & 17.1 & 16.5 & 15.9 & 18.0 & 15.1 \\
\hline & \multicolumn{5}{|c|}{ Private household plots } \\
\hline $\begin{array}{l}\text { Sheep and goats in slaughter weight, '000 } \\
\text { metric tons }\end{array}$ & 71.3 & 70.7 & 69.8 & 68.7 & 67.9 \\
\hline Wool (in physical weight), metric tons & 49.1 & 47.3 & 47.2 & 46.5 & 46.7 \\
\hline & \multicolumn{5}{|c|}{$\begin{array}{c}\text { Peasant (farm) enterprises and } \\
\text { individual entrepreneurs }\end{array}$} \\
\hline $\begin{array}{l}\text { Sheep and goats in slaughter weight, '000 } \\
\text { metric tons }\end{array}$ & 20.8 & 21.7 & 23.1 & 23.5 & 24.5 \\
\hline Wool (in physical weight), metric tons & 33.8 & 36.2 & 36.9 & 35.5 & 38.2 \\
\hline
\end{tabular}

The wool they obtain is of low quality.Private household plots and most peasant (farm) enterpriseskeep coarse-wool and crossbred sheep intended mainly for the production of mutton meat and having low-quality wool. Selection and breeding work aimed at improving the quality of wool is not carried out in farms of these categories.

The growth in wool production in recent years has been facilitated by the improved pricing situation for sheep products and the subsidy for wool production introduced by the government in 2015. High-quality wool is in demand.The price for fine wool reaches 300 rubles / $\mathrm{kg}$. It cost about 50 rubles / $\mathrm{kg}$ ten years ago and about 100 rubles $/ \mathrm{kg}$ five years ago.

The growth in mutton production was also facilitated by the rise in purchase prices. About five years ago, lamb in live weight was sold for 105 to 110 rubles. Currently, the purchase price of lamb meat can be up to 400 rubles / $\mathrm{kg}$ and 280-300 rubles / $\mathrm{kg}$ for young mutton. Retail prices can reach 800 to 1,000 rubles / $\mathrm{kg}$ depending on the cutting and packaging. 
Experts estimate the potential internal capacity of this meat segment as large.Mutton in the diet of an average Russianwas $1.4 \mathrm{~kg}$ (12 kg in 1960 and $2.5 \mathrm{~kg}$ in 1990) in 2016 [8]. The lamb market shows trends of increasing demand and consumption including those due to the shift in demand from pork to beef and lamb.

In general, sheep breeding is developing in accordance with the task of developing export potential designated by the government. Young mutton and lamb have high export potential, which shows growth: exports amounted to 460 metric tons in 2017 and 12,400 metric tons in 2018. Received amount of $\$ 30.1$ million not only exceeded the size of beef exports, but also became comparable to the export of pork (\$40.4 million). In 2019, exports decreased due to the current unfavorable situation in the industry. According to the National Union of Sheep Breeders, 11,500 metric tons of lamb and mutton or about 520,000 heads of sheep were exported only to Iranin 2019, which cost $\$ 52.5$ million [11].

The genetic resources of sheep breeding in Russia are represented by 44 breeds of sheep including 15 fine-wool, 13 semi-fine-wool, 2 semi-coarse-wool and 14 coarse-wool breeds. Breeding work is carried out by 210 breeding organizations including 42 breeding plants, 152 breeding reproducers, 13 gene pool farms and 3 breeding and genetic centers [12].

The government's strategy in the medium term is to improve the quality and competitiveness of products in the world market while meeting internal needs for mutton and wool and developing export potential. Strategic development guidelines for the next ten years are reflected in the draft Strategy for the Development of Sheep and Goat Breeding in the Russian Federation (Table 3).

Table 3. Indicators of the draft Strategy for the Development of Sheep and Goat Breeding in the Russian Federation [11].

\begin{tabular}{|c|c|c|c|c|c|}
\hline \multirow[b]{2}{*}{ Year } & \multirow[b]{2}{*}{ Indicators } & \multicolumn{3}{|c|}{ Breeds } & \multirow[b]{2}{*}{ Total } \\
\hline & & Fine-wool & $\begin{array}{c}\text { Semi- } \\
\text { fine-wool }\end{array}$ & $\begin{array}{c}\text { Coarse-wool, } \\
\text { semi-coarse-wool }\end{array}$ & \\
\hline & $\begin{array}{l}\text { Share of livestock in } \\
\text { the total number, \% }\end{array}$ & 59.7 & 5.0 & 35.3 & 100 \\
\hline \multirow{3}{*}{2017} & Livestock, ' 000 heads & 14,694 & 1,286 & 8,583 & 24,563 \\
\hline & Cut per single head, kg & 2.5 & 3.5 & 1.7 & \\
\hline & $\begin{array}{l}\text { Wool output, metric } \\
\text { tons }\end{array}$ & 37,859 & 4,501 & 14,375 & 56,735 \\
\hline \multirow{3}{*}{2020} & Livestock, ' 000 heads & 14,753 & 1,299 & 8,660 & 24,712 \\
\hline & Cut per single head, kg & 2.6 & 3.5 & 1.7 & \\
\hline & $\begin{array}{l}\text { Wool output, metric } \\
\text { tons }\end{array}$ & 38,359 & 4,546 & 14,722 & 57,628 \\
\hline \multirow{2}{*}{2023} & $\begin{array}{l}\text { Livestock, ' } 000 \text { heads } \\
\text { Cut per single head, kg }\end{array}$ & $\begin{array}{c}14,893 \\
2.6\end{array}$ & $\begin{array}{c}1,311 \\
3.5\end{array}$ & $\begin{array}{c}8,743 \\
1.7\end{array}$ & 24,947 \\
\hline & $\begin{array}{l}\text { Wool output, metric } \\
\text { tons }\end{array}$ & & 4,589 & 14,863 & 58,175 \\
\hline \multirow{3}{*}{2025} & Livestock, '000 heads & 15,016 & 1,325 & 8,811 & 25,152 \\
\hline & Cut per single head, kg & 2.7 & 3.5 & 1.76 & \\
\hline & $\begin{array}{l}\text { Wool output, metric } \\
\text { tons }\end{array}$ & 40,542 & 4,638 & 15,560 & 60,740 \\
\hline
\end{tabular}

Recently, more and more attention has been paid to the meat production in sheep breeding, which is due to the growing global demand for lamb and mutton and their high export potential. According to experts, industrial meat sheep breeding should provide up to $70 \%$ of mutton from the gross production in the country. The transition to industrial meat production will require the introduction of modern scientific developments and technological solutions, as well as the use of scientifically based hybridization systems [7].

Currently, Russia does not have a gene pool of highly productive dedicated meat breeds that fully meet up-to-date requirements. The creation of such a gene pool is an urgent task 
of domestic sheep-breeding science and practice. A segment of large mutton producers using high-tech industrial production is just emerging in the country.

Over the past few years, a number of new enterprises have been built, which specialize in the slaughter of sheep and the deep processing of mutton. Such enterprises are Uspekh located in the Stavropol Territory, Chaban situated in Kalmykia, and Boztorgay and AgroDagItalia located in Dagestan. A number of large agricultural holdings (Resource Group of Companies, N. Tkachev Agrokomplex) are currently working on complete cycle projects including both the production of mutton on an industrial basis and its deep processing. This indicates the prospects for the area in the agro-industrial animal husbandry in Russia. An industrial branch of mutton production, which will include industrial production, fattening and slaughter, will be establishedin the next three to five years [13].

Trends in the increasing demand for lamb, a decrease in the number of fine-wool sheep breeds and an increase in the number of meat and meat and lard breeds influenced the vector of scientific research. Scientific research institutes and breeding centers are working on the creation of new meatsheep breeds and on the preservation of the population of Romanov sheep.

Fifteen research institutes and five educational organizations carry out scientific research in the field of sheep breeding. The accumulated scientific experience has made it possible to create in the last decade 13 breeds and 12 breed types characterized by high productivity in various natural and climatic zones of the country. A system of genetic monitoring based on immunogenetic methods has been created and used in practice. Methods of genomic selection of sheep are being developed $[11,14,15]$.

Significant scientific groundwork and practical results have been formed:

- $\quad$ Promising breeds and types of sheep characterized by high productivity in various natural and climatic zones of the country have been created;

- A system of genetic monitoring based on immunogenetic methods has been created and used in practice;

- Development of methods for genomic selection of sheep and goats is underway provided by the high level of domestic scientific schools in the field of molecular genetics, genomics and bioinformatics;

- Up-to-date systems of feeding and keeping sheep and goats, as well as technologies for creating highly productive pastures are being developed;

- Development of new drugs and methods of their application is underway to ensure the veterinary welfare and health of small ruminants;

- A regulatory framework for sheep and goat breeding has been elaborated to ensure that sheep products comply with world quality standards.

So, the sheep breeding and feeding laboratoryat the Federal Research Center for Animal Husbandry named after Academy Member L.K. Ernsthas created Tashlinskaya breed (sheep meat breed) and southern meat breedbased on the Texel sheep meat breed. In the Stavropol Territory, an array of fine-fleece sheep with improved meat quality and superfine wool is createdin fine-fleece sheep breedingusing Australian meat merino sheep.

Employees of the sheep breeding and feeding laboratory at the Federal Research Center for Animal Husbandry named after Academy Member L.K. Ernst created at Oktyabrskoye LLC, Ryazan region, a new meat and fur type of sheep with increased viability and improved meat qualitybased on meat and wool sheep of the Romney Marsh type and rams of the Romanov breed, with the preservation of multiplicity, polyesterity and high fur qualities inherent in sheep of the Romanov breed. Aitax-Milk started working on the creation of a meat type with increased early maturity and meat qualitiesbased on Volgograd sheep and Suffolk beef rams $[7,16,17]$. 
Large manufacturers of sheep and goat products have appeared in the industry that not only actively usecurrent technologies, but also implement their own scientific and technological projects.

\section{Conclusions}

Sheep farming is actively developing globally and the world livestock and the demand for the products of the sub-industry (super-fine wool and meat) are growing. Those countries that have developed sheep breeding are performing selection and breeding work to improve the quality of wool and increase the efficiency of the meat sector, as well as to support and promote the export of sheep products. There is a worldwide tendency to reorient the wool sector to meat sector.A large number of breeds showing high fattening resultshave been bred.

Since the total consumption of wool in the world is decreasing with a relatively stable demand for ultra-thin and super-thin wool, which has a rather high cost, it is advisable to conduct selection and breeding work to thin the fineness of wool and stimulate the production of fine wool with increased subsidies from the government.

In Russia, there is a stable growth in the production of lamb, which increased exports from 460 metric tons in 2017 to 12,400 metric tons in 2018.In 2019, meat production decreased due to unfavorable circumstances for the industry: a decrease in the volume of the feed base and veterinary restrictions on the movement of livestock.

The main producers of sheep products in the industry are private household plots, peasant (farm) enterprises and individual entrepreneurs, which are currently poorly engaged in selection and breeding work and the introduction of innovations, show low indicators of animal productivity and produce wool of low quality, while ultra-thin quality wool is in demand on the market. Therefore, it is advisable to provide support measures that stimulate selection and breeding work and the introduction of innovations when developing regional support measures.

The emerging sheep meat sector is implementing large projects with large production capacities and the introduction of innovative technologies, such as projects of the holdings Miratorg and AgriVolga Holdings, and the Damate Group. Such rates are able to contribute to solving the tasks set by the state to increase the export of sheep breeding products. Scientific research institutions of the industry are working on solving the problem of creating a gene pool of highly productive dedicated meat breeds that fully meet current requirements, as well as on the development of innovative technologies. Their projects should be fully used both by the industrial sector, private household plots and peasant (farm) enterprises to increase their product quality and production efficiency. The development and implementation of the FSTP subprogram titled "Improving the genetic potential of small ruminants" and the involvement of private household plots and farmers in its implementation will greatly contribute to the solution of the primary tasks in the industry.

\section{References}

1. National report on the progress and results of the implementation in 2019 of the state program for the development of agriculture and regulation of markets for agricultural products, raw materials and food,https://mcx.gov.ru

2. I. F. Gorlov, M.I. Slozhenkina, O.P. Shakhbazova, R.G. Radzhabov, N.V. Ivanova, E.Yu. Anisimova, O.A. Knyazhechenko, IOP Conf. Ser.: Earth Environ. Sci. (2020) 
3. Report on the implementation in 2018 of the Action Plan of the Ministry of Agriculture of the Russian Federation for 2016 - 2021,http://www.consultant.ru

4. The Ministry of Agriculture will develop a strategy for the development of sheep and goat breeding,http://mcx.ru

5. E.A. Krasnoperova, I.M. Donnik, Yu.A. Yuldashbaev, M.G. Leshcheva, V.N. Kulakov, S.O. Chylbak-ool, Bulletin of the National Academy of Sciences of the Republic of Kazakhstan, 6(388), 100 (2020)

6. Livestock systems, http://www.fao.org

7. V.N. Kuzmin, T.E. Marinchenko, A.P. Korolkova, Machinery and equipment for rural area, 12(270), 2 (2019)

8. T. Khamiruev, B. Bazaron, V. Chernykh, I. Volkov, O.Dabaev, Russian Agricultural Sciences, 44, 350 (2018)

9. B.B. Traisov, D.B. Smagulov, Y.A. Yuldashbaev, K.G. Esengaliev, Journal of Pharmaceutical Sciences and Research, 9(5), 574 (2017)

10. K.A. Kulikova, Y.A. Yuldashbaev, P. M. Petrovic, V.C. Petrovic, D.R. Muslic, N. Maksimovic, D.O. Andric, Genetika, 50(3), 885 (2018)

11. National Union of Sheep Breeders, http://agrofarm.vdnh.ru

12. 2018 Yearbook on breeding work in sheep and goat breeding on the farms of the Russian Federation (2019)

13. A.I. Erokhin, E.A. Karasev, S.A. Erokhin, Sheep, goats, wool business, 1, 29 (2018)

14. T.N. Khamiruev, B.Z. Bazaron, V.G. Chernykh et al, Russ. Agricult. Sci.,44, 350 (2018)

15. Yu.A. Yuldashbayev, A.F. Shevhuzhev, R.Kh. Kochkarov, E.G. Mishvelov, A.I. Ponomareva, Research Journal of Pharmaceutical, Biological and Chemical Sciences, 9(4),692 (2018)

16. Russian sheep breeding: current realities, https://www.agroxxi.ru

17. S.I. Novopashina et al., State of and promising areas for improving the genetic potential of small ruminants (2019) 